\title{
COMMUNICATION OF TEACHERS AND DISCIPLES IN DIGITAL ERA (DESKIPTIF QUALITATIF DISTRIBUTION OF LEARNING INFORMATION THROUGH WHATSAPP SOCIAL MEDIA IN THE MIDDLE SCHOOL (SMA) BUDI LUHUR, CILEDUG)
}

\author{
Rahajeng Puspitosari \\ Universitas Budi Luhur, Indonesia. \\ rahajeng.puspitosari@budiluhur.ac.id
}

\begin{abstract}
The purpose of this study is to find out how teacher and student communication in the Digital Age (Case study of learning information dissemination through Whatsapp social media in Budi Luhur High School, Ciledug. This study uses a qualitative approach with qualitative descriptive methods. Data collection techniques conducted with in-depth interviews and observations. This study uses the Innovation Diffusion theory from Rogers. The results of this study indicate that there are a number of things that occur in teacher and student communication in the Menengah School of Budi Luhur associated with the use of Whatsapp social media, namely the existence of communication innovations in the communication relationship between teachers and students in Budi Luhur Ciledug high school, the existence of a modern communication channel at Budi Luhur high school that facilitates the flow of information exchange, a relatively short period of time using social media, and changes in social systems in social communication. This change certainly has positive and negative impacts on teacher and student communication.
\end{abstract}

Keywords: Mass Communication, Information Dissemination, Whatsapp Social Media

\section{INTRODUCTION}

Dissemination of learning information is something that must be considered so that learning activities become more optimal and the objectives of learning can be achieved. Dissemination of learning information has often been constrained due to limited communication space. Limited communication space makes information dissemination ineffective and miss communication often occurs. However, today many communication technologies are designed to facilitate the dissemination of information. One of the technology products that people are interested in is the internet. Based on a survey conducted by the Indonesian Internet Service Providers Association (APJII), information was obtained that the number of internet users in Indonesia reached 132.7 million in 2016 and 97.4 percent of internet users in Indonesia used social media.

This research focuses on the use of WhatsApp social media, because WhatsApp is the most popular social media by the public. WhatsApp is a social media application designed to facilitate users in communicating through various available features. Some features of the WhatsApp application include Chat Group, WhatsApp on the Web and Desktop, WhatsApp Voice and Video Calls, End-to-End Encryption, Photo and Video Sending, Voice Messaging, and Documents. WhatsApp social media through various features provided can be used for more useful activities, for example for education. This research was conducted at High Schools This research was conducted to find the effect of using the WhatsApp application on the dissemination of learning information at the Senior High School level. Previously, researchers had made observations at one high school in Budi Luhur High School, Ciledug. and found information that at this time the school, students, and teachers have been communicating and disseminating information related to learning activities through WhatsApp.

This study uses the theory of Innovation Diffusion from Rogers (1961). There are four main elements of innovation diffusion, namely: (1) Innovation; ideas, actions, or items that are considered new by someone. In this case, the novelty of innovation is measured subjectively according to the view of the individual who receives it. If an idea is considered new by someone then it is an innovation for that person. The 'new' concept in an innovative idea doesn't have to be new at all. (2) Communication channels; 'Tools' to convey messages of innovation from the source to the recipient. In choosing a communication channel, the source must at least pay attention to (a) the purpose of the communication and (b) the characteristics of the recipient. If communication is intended to introduce an innovation to a large and wide audience, then a more precise, fast and efficient communication channel is mass media. But if communication is intended to change the attitude or behavior of the recipient personally, then the most appropriate communication channel is the interpersonal channel. (3) Duration; the innovation decision process, from knowing someone to deciding to accept or reject it, and the confirmation of that decision is closely related to the time dimension. At least the time dimension is seen in (a) the process of innovation decision making, (b) the innovativeness of a person: relatively earlier or slower in 
accepting innovation, and (c) the speed of adoption of innovation in social systems. (4) Social system; a collection of different units functionally and bound in cooperation to solve problems in order to achieve common goals.

This study also took the concept of communication from Ruben and Steward (1998), the concept of Dissemination of Learning Information, and the concept of social media. This study uses the Post Positivism paradigm with a qualitative descriptive research approach. The subjects in this study were two teachers at Budi Luhur Ciledug High School and 3 students who were students of Budi Luhur Ciledug High School. While the object of this study is the social media Whatsapp as a communication medium for the dissemination of learning information between teachers and students in high school Budi Luhur Ciledug. Data collection techniques in this study were carried out by in-depth interviews with all speakers and also by observing. The research location was held at Budi Luhur High School, Jalan Raden Saleh No. 999 Karang Tengah Tangerang. The validity of the data is done by using the validity of the source, which is towards the validity of the data through the source which is made the informant by the researcher.

\section{RESEARCH RESULT}

There are several results from this study, namely:

Whatsapp Group is an innovative communication between teachers and students at Budi Luhur High School

Communication is a process of delivering a communicator's data message to the communicant using the media. In the process of communication, it can be done in various ways. As was done by teachers at Budi Luhur High School. Budi Luhur High School as a school that prioritizes advances in technology and information has now encouraged all teachers and staff to be able to communicate digitally. Both with students, parents guardians of students and even with peers and staff in Budi Luhur High School. Whatsapp group was chosen as the media believed to be able to answer the needs of the public at Budi Luhur High School as an innovation in communication. Whatsapp group is considered as an application that facilitates the process of delivering messages and information both from teacher to student and teacher to student guardians. The use of Whatsapp group is chosen based on agreement with all class. But in Budi Luhur High School there are several classes that also use Line groups as a medium for delivering information. This is because the line is considered more representative of the millennial generation with emoticons that can support the delivery of messages. With the use of Whatsapp social media information relating to lessons and activities at school becomes more efficient. In addition Whatsapp group or line group is considered as a media to strengthen relationships between teachers and students. The close relationship that occurs between teachers and students at Budi Luhur High School is reflected in informal communication patterns as well as material or topics of conversation that are not only about lessons but also topics that can liven up a group atmosphere.

Progress in the field of communication has a big impact in the process of communication between teachers and students at Budi Luhur High School. Information becomes fast and on target so students can understand the message conveyed. With the rapid process of disseminating information, making students more productive and efficient. For example, in the delivery of assignments, if there are things that are not understood by students, Whatsapp group can be discussed again. This allows more information and knowledge to be obtained by students.

Social systems and changes in norms in the process of communication between teachers and students at Budi Luhur High School

The advancement of communication technology brings various impacts, both positive and negative impacts. The positive impact resulting from the advancement of communication technology naturally impacts on speed and time efficiency. But the negative impact was also felt. One of them is by changing the norms of students. With the Whatsapp group where teachers and students can communicate more informally, it makes students less likely to be polite and not communicate as they should. They tend to behave and consider the teacher as their partner. This is the teacher's concern, where students no longer have the norms of courtesy. The teacher has the obligation to reprimand the student so that they still have the norms and regulations in force. Budi Luhur High School has a binding regulation whereby all students who violate norms and grades will be subject to sanctions "The Merit". This sanction is a reduction in grades for students who break the rules. If the grade given is finished (each student gets 100 points), the student is threatened with expulsion from the school. Vice versa, if students have positive grades, will get additional points.

The communication in the Whatsapp group is also influenced by those in the group. If the teacher has a strict nature, students tend to be inactive and rarely communicate in the group. It is different with teacher kar tendr which tends to be fun, students will more actively communicate and discuss various things outside the context of learning and activities in school. 
Whatsapp Group has an entertainment function for teachers and students at Budi Luhur High School

Communication through social media has many benefits. As happened to the Whatsapp group that is used by teachers and students at Budi Luhur High School as a means of communication. On Whatsapp Group, it does not only convey information, but also entertainment. This relates to informal communication carried out by students and teachers. Sometimes there are jokes made by students and teachers that make the group atmosphere more pleasant and warm. Communication that occurs through Whatsapp group social media also occurs on holidays. They continue to discuss and communicate outside the context or school activities

Barriers to communication using Whatsapp Group between teachers and students at Budi Luhur High School

Communication made using Whatsapp group also has various obstacles. One of them is that there are some students who do not always open a group on the grounds that the communication tool is damaged, so the message or information delivered cannot be well received by all students. The teacher has an obligation to always encourage students to always be up to date with the group and the information conveyed. In addition, students are also required to inform if there is a replacement of mobile phone numbers so that all students can receive information optimally.

\section{CONCLUSION}

The conclusion of this study is the communication that occurs between teachers and students in high school Budi Luhur Ciledug after using Whatsapp social media to experience some changes, including: changes in how to communicate, using Whatsapp is believed to facilitate the communication process between teachers and students in Budi's high school Luhur Ciledug in terms of time and the relationship that was built became more intimate. Furthermore, there are also changes in social systems that occur due to the use of Whatsapp social media such as the lack of distance between teacher and student that students should be able to remain polite to their teacher. Whatsapp group is sometimes not used properly, the contents of conversations on Whatsapp Group often contain things outside of learning information.

\section{REFERENCES}

Abdulhak, Ishak dan Deni Darmawan, 2015. Teknologi Pendidikan.Bandung: PT Remaja Rosdakarya.

Ghozali, Imam. 2013. Aplikasi Analisis Multivariate dengan Program IBM SPSS 21. Semarang: Badan Penerbit Universitas Diponegoro.

Hanafi, Abdillah. 1987. Memasyarakatkan Ide-Ide Baru. Surabaya: Penerbit Usaha Nasional

Idris Soenarto, Ali. 2015. Metodologi Penelitian dengan Aplikasi Statistika. Depok: PT Taramedia Bakti Persada.

Little Jhon, Stephen W dan Karen A. Foss. 2009. Theories of Human Communication. ed, terj. Mohammad Yusuf Hamdan, Jakarta: Salemba Humanika.

Nasrullah, Rulli. 2017. Media Sosial (Prespektif Komunikasi, Budaya, dan Sosioteknologi). Bandung: Simbiosa Rekatama Media.

Pawit M. Yusup. 2009. Ilmu Informasi, Komunikasi, dan Kepustakaan, Jakarta: PT. Bumi Aksara.

Rogers, E.M. dan Shoemaker, F.F. 1971. Communication of Innovations, London: The Free Press.

Rogers, Everett M. 1983. Diffusion of Innovations. London: The Free Press.

Rogers, Everett M. 1995. Diffusions of Innovations, Forth Edition. New York: Tree Press.

Sugiyono. 2011. Metode Penelitian Kuantitatif, Kualitatif, dan R\&D, Cetakan ke-14. Bandung: Alfabeta.

Widarjono, Agus. 2010. Analisis Statistika Multivariat Terapan, Yogyakarta: Sekolah Tinggi Ilmu Manajemen YKPM.

Hendro Kusumo dan Eko Prasetyo Moro. 2016. Pengaruh Penggunaan WhatsApps Messenger terhadap Prestasi Belajar Mahasiswa Kelas KKH di PBIO FKIP UAD, Universitas Ahmad Dahlan. 